\title{
PENGEMBANGAN MEDIA PEMBELAJARAN INTERAKTIF MATEMATIKA KELAS VI SD/MI
}

\author{
Susilo', Abdul Hasan Saragih', Sahat Siagian ${ }^{3}$ \\ MIN Padang Bulan Rantauprapat ${ }^{1}$ dan PPs Universitas Negeri Medan ${ }^{2,3}$ \\ susilo.7lo.7lo@yahoo.com
}

\begin{abstract}
Abstrak: Studi ini bertujuan untuk : (1) menghasilkan produk media pembelajaran interaktif berbasis Macromedia Flash Profesional 8 yang berkualitas pada mata pelajaran matematika materi geometri untuk siswa kelas VI MIN Padang Bulan Rantauprapat yang layak digunakan dalam pembelajaran (2) mengetahui efektifitas penggunaan media pembelajaran interaktif berbasis Macromedia Flash Profesional 8 pada mata pelajaran matematika materi geometri untuk siswa kelas VI MIN Padang Bulan Rantauprapat. Jenis penelitian ini adalah penelitian pengembangan yang menggunakan model pengembangan produk Borg dan Gall yang dipadu dengan model pengembangan pembelajaran Dick dan Carey. Model ini meliputi enam tahapan, yakni: studi literatur, perencanaan atau desain pengembangan, pengembangan produk, validasi ahli, uji coba, revisi, produk akhir. Data tentang kualitas produk pengembangan ini dikumpulkan dengan angket. Data-data yang dikumpulkan dianalisis dengan teknik analisis deskriptif kualitatif. Hasil pengembangan media interaktif menunjukan validasi ahli menunujukkan bahwa keseluruhan rata-rata dikategorikan "Sangat Baik" dan uji kelayakan menunujukkan bahwa keseluruhan rata-rata dikategorikan "Sangat Baik". Hasil pengujian hipotesis membuktikan bahwa terdapat perbedaan yang signifikan antara hasil belajar siswa yang dibelajarkan dengan menggunakan media pembelajaran interaktif Macromedia Flash dengan hasil belajar siswa yang dibelajarkan dengan pembelajaran konvensional.
\end{abstract}

Kata kunci: Media Pembelajaran Interaktif, Matematika

\begin{abstract}
Abstrack: This study aims to: (1) produce a qualified interactive learning media based Macromedia Flash profesional 8 in mathematics material geometry for students of class VI MIN Padang Bulan Rantauprapat are eligible for use in learning (2) determine the effectiveness of the use of interactive learning media-based Macromedia flash profesional 8 in mathematics materials for students of class VI geometry MIN Padang Bulan Rantauprapat. This type of research is the development of research that uses models Borg and Gall product development combined with learning development model of Dick and Carey. This model includes six stages, namely: literature studies, planning or design development, product development, validation expert, testing, revision, the final product. Data about the quality of the products of this development are collected by questionnaire. The data collected were analyzed using qualitative descriptive analysis techniques. The results of development of Interactive LearningMedia by Experts' validation indicate that the overall average categorized "Very Good" And the Feasibility test indicate that the overall average categorized "Very Good". Hypothesis testing results show that there are significant differences between the students learning outcomethat to be learned by using Macromedia Flash Interactive Learning Media and Students learn outcometo be learned by conventional learning.
\end{abstract}

Keywords: Interactive Learning Media, Mathematic

\section{PENDAHULUAN}

Kegiatan pembelajaran disekolah merupakan kegiatan utama dalam peningkatan kualitas pendidikan nasional. Melalui proses belajar mengajar diharapkan tercapai tujuan pendidikan dalam bentuk perubahan tingkah laku peserta didik. Proses belajar ini memerlukan keterampilan untuk memungkinkan manusia saling berhubungan dan berkomunikasi, saling berbagi pengalaman, belajar dari yang lain, dan meningkatkan intelektualitas diri.

Hal ini sesuai dengan tujuan pembelajaran matematika yaitu (1) memahami konsep matematika, menjelaskan keterkaitan antara konsep dan mengaplikasikan konsep atau algoritma, secara luwes, akurat, efesien, dan tepat dalam pemecahan masalah, (2) menggunakan penalaran pada pola dan sifat, melakukan manipulasi matematika dalam membuat generalisasi, menyusun bukti, atau menjelaskan gagasan dan pernyataan 
matematika, (3) memecahkan masalah yang meliputi kemampuan memahami masalah, merancang model matematika, menyelesaikan model, dan menafsirkan solusi yang diperoleh, (4) mengomunikasikan gagasan dengan simbol, tabel, diagram, atau media lain untuk memperjelas keadaan atau masalah, (5) memiliki sikap menghargai kegunaan matematika dalam kehidupan, yaitu memiliki rasa ingin tahu, perhatian, dan minat dalam mempelajari matematika, serta sikap ulet, dan percaya diri dalam pemecahan masalah ( Depdiknas, 2006 : 417). Adapun ruang lingkup materi atau kajian matematika di SD/MI mencakup : (a). Bilangan, (b). Geometri dan Pengukuran, dan (c). Pengolahan Data.

MIN Padang Bulan adalah sekolah dasar dibawah naungan Kementerian Agama yang setingkat dengan Sekolah Dasar dan merupakan salah satu sekolah favorit di Kecamatan Rantau Utara Kabupaten Labuhanbatu karena memiliki kelebihan dalam bidang agama dan sekolah berwawasan lingkungan tingkat nasional yang belum dimiliki sekolah lain di sekitarnya. Namun favorit dalam bidang agama dan sekolah berwawasan lingkungan ternyata tidak seimbang dengan hasil belajar siswa khususnya pada mata pelajaran matematika.

Menurut keterangan guru bidang studi matematika kelas VI MIN Padang Bulan Rantauprapat umumnya disebabkan para siswa cenderung mengalami kesulitan memahami bagaimana cara menjawab pertanyaan guru terkait materi matematika dengan tepat. Artinya, masalah juga terdapat pada guru-guru matematika yang kurang mampu menjelaskan materi secara tepat dan sederhana.

Mata pelajaran matematika adalah salah satu mata pelajaran wajib yang ada di SD/MI sesuai dengan kurikulum yang telah ditetapkan di Indonesia. Bilangan , geometri dan pengukuran, dan pengelolaan data adalah salah satu materi yang dipelajari dalam kurikulum tersebut. Namun dalam penyelenggaraan pembelajaran matematika di MIN Padang Bulan banyak kendalah-kendalah yang dihadapi oleh guru antara lain: (1) alat bantu mengajar yang masih kurang, (2) materi/bahan ajar yang masih sulit diperolah diperpustakaan, (3) aktivitas siswa yang masih rendah dalam pembelajaran, (4) siswa tidak/kurang kreatif dan inovatif dalam pengerjaan tugas, (5) hasil belajar (nilai mata pelajaran) berupa tugas atau latihan pada umumnya masih rendah, (6) siswa sering mengabaikan pelajaran matematika karena hanya fokus pada pelajaran agama yang dianggap lebih menarik.

Media pembelajaran merupakan wahana dan penyampaian informasi atau pesan pembelajaran kepada siswa. Dengan adanya media pada proses belajar mengajar diharapkan dapat membantu guru untuk meningkatkan prestasi belajar siswa. Menurut Arsyat (2013:10), Media pembelajaran adalah segala sesuatu yang dapat digunakan untuk menyampaikan pesan atau informasi dalam proses belajar mengajar sehingga dapat merangsang perhatian dan minat siswa dalam belajar. Media pembelajaran merupakan seperangkat alat bantu atau perlengkapan yang digunakan oleh guru atau pendidik dalam rangka berkomunikasi dengan siswa atau peserta didik. Materi yang dikemas melalui media akan lebih jelas, lengkap dan menarik bagi siswa. Media pembelajaran juga berfungsi untuk meningkatkan kualitas proses pembelajaran. Pada umumnya hasil belajar siswa dengan menggunakan media pembelajaran akan lebih tahan lama mengendap sehingga kualitas pembelajaran memiliki nilai yang tinggi (Rudi susilana \& Cepi Riyana, 2007:10)

Menurut kamus bahasa indonesia interaktif berarti bersifat saling melakukan aksi; antar-hubungan; saling aktif berkaitan dengan dialog antara komputer dan terminal atau antara komputer dan komputer. Interatif berasal dari kata interaksi, yaitu hal saling melakukan aksi, berhubungan, mempengaruhi, antar hubungan. Interaksi terjadi karena adaya hubungan sebab akibat, yaitu adanya aksi dan interaksi. pembelajaran interaktif adalah mengajak siswa untuk melibatkan pikiran, penglihatan, pendengaran dan keterampilan sekaligus, salah satunya adalah sambil menulis. Dengan proses belajar interaktif, siswa dirangsang untuk bertanya, menjawab dan mengemukakan pendapatnya dan disaat yang sama mengerjakan tugas yang diberikan guru, baik itu tugas perseorangan maupun kelompok. Sistem belajar ini juga tidak menekankan pada hasil melaikan pada proses. Sehingga siswa memperoleh pengetahuan bukan dengan cara menghafal, tetapi dengan cara mengalami. media pembelajaran interaktif adalah media yang dapat menyajikan pembelajaran secara interaktif yang dapat merespon siswa secara aktif.

Macromedia Flash merupakan sebuah 
program yang didesain khusus oleh Macromedia, saat itu sebagai pengembangnya yang saat ini sudah dibeli oleh Adobe Incorporated sehingga berubah nama menjadi Adobe Flash, Flash didesain dengan kemampuan untuk membuat animasi 2 dimensi yang handal dan ringan sehingga flash banyak digunakan untuk membangun dan memberikan efek animasi pada website, CD Interaktif dan yang lainnya. Keunggulan yang dimiliki oleh Flash ini adalah ia mampu diberikan sedikit code pemograman baik yang berjalan sendiri untuk mengatur animasi yang ada didalamnya atau digunakan untuk berkomunikasi dengan program lain seperti HTML, PHP, dan Database dengan pendekatan XML.

Istilah matematika berasal dari bahasa Yunani mathematika yang mempunyai kata mathema yang berarti ilmu atau pengetahuan. Kata matematika juga berhubungan dengan kata yang serupa, yaitu mathanein yang berarti belajar atau berfikir. Hakikat matematika sebagai ratu atau ibunya ilmu dimaksudkan bahwa matematika adalah sebagai sumber dari ilmu yang lain. Dimana matematika tumbuh dan berkembang untuk dirinya sendiri sebagai suatu ilmu. Matematika juga sebagai pelayan ilmu karena melayani kebutuhan ilmu pengetahuan dalam pengembangan dan operasionalnya. Hakikat matematika disebut sebagai ilmu tentang pola karena pada matematika sering dicari keseragaman seperti keterurutan, keterkaitan pola dari sekumpulan konsep-konsep tertentu atau model yang merupkan representasinya untuk membuat generalisasi dan matematika disebut ilmu tentang hubungan karena konsep matematika satu dengan lainnya saling berhubungan.

Ditingkat Sekolah Dasar, mata pelajaran matematika yang diajarkan pada KTSP (Kurikulum Tingkat Satuan Pelajaran) meliputi: bilangan, geometri dan pengukuran, dan pengelolaan data. Sementara itu tujuan pembelajaran matematika adalah : (1) memahami konsep matematika, menjelaskan keterkaitan antara konsep dan mengaplikasikan konsep atau algoritma, secara luwes, akurat, efesien, dan tepat dalam pemecahan masalah, (2) menggunakan penalaran pada pola dan sifat, melakukan manipulasi matematika dalam membuat generalisasi, menyusun bukti, atau menjelaskan gagasan dan pernyataan matematika, (3) memecahkan masalah yang meliputi kemampuan memahami masalah, merancang model matematika, menyelesaikan model, dan menafsirkan solusi yang diperoleh, (4) mengomunikasikan gagasan dengan simbol, tabel, diagram, atau media lain untuk memperjelas keadaan atau masalah, (5) memiliki sikap menghargai kegunaan matematika dalam kehidupan, yaitu memiliki rasa ingin tahu, perhatian, dan minat dalam mempelajari matematika, serta sikap ulet, dan percaya diri dalam pemecahan masalah (Depdiknas, 2006:417).

Berbagai pertimbangan yang telah disampaikan dari kemudahan yang diperoleh dalam pembelajaran dari penggunaan teknologi atau media pembelajaran sangat penting kiranya untuk mengembangkan multimedia interaktif untuk mata pelajaran matematika di MIN Padang Bulan guna mewujudkan tujuan pendidikan dalam bentuk perubahan tingkah laku peserta didik serta meningkatkan kualitas proses dan produk pembelajaran, utamanya dalam mengubah paradigma pembelajaran kearah yang lebih inovatif, konstruktif dalam dinamika perkembangan teknologi yang pesat sehingga hasil belajar siswa menjadi meningkat.

Multimedia yang dimaksud dalam penelitian ini adalah suatu penggunaan gabungan beberapa media dalam menyampaikan informasi yang berupa teks, grafis, video dan audio dalam aplikasi komputer. Interaktif yang dimasud adalah kemampuan penggunaan untuk mengontrol atau menentukan urutan materi pembelajaran yang sesuai dengan keinginan atau kebutuhan pengguna yang dikemas dalam Macromedia Flash Profesional 8.

Berdasarkan latar belakang dan batasan masalah diatas, maka masalah penelitian ini dirumuskan sebagai berikut : (1) Apakah media pembelajaran interaktif berbasis Macromedia Flash Profesional 8 yang dikembangkan layak digunakan pada bidang studi matematika dalam membantu siswa belajar ?; (2) Apakah media pembelajaran interaktif berbasis Macromedia Flash Profesional 8 efektif pada bidang studi matematika?

\section{METODE}

Penelitian ini dilaksanakan di MIN Padang Bulan Rantauprapat berlokasi di Jalan Padang Bulan Gang PGRI No.50 Rantauprapat dan SD Negeri 112143 Rantauprapat Jalan Ahmad Yani Rantauprapat tahun pelajaran 2016/2017. Tahap pelaksanaan penelitian ini dilaksanakan pada semester ganjil tahun pelajaran 2016/2017 dengan sampel yang terdiri 
dari satu kelas berjumlah 30 orang peserta didik. Waktu pelaksanaan penelitian ini mulai bulan Agustus 2016.

Metode penelitian yang digunakan adalah research and development, karena penelitian ini termasuk penelitian pengembangan pendidikan yang dimaksudkan untuk menghasilkan produk pembelajaran yang layak dimanfaatkan dan sesuai kebutuhan. Borg \& Gall (1983) yang dipadu dengan model pengembangan pembelajaran Dick dan Carey (2005).

\section{Prosedur Pengembangan}

Prosedur pengembangan yang ditempuh untuk menghasilkan produk media pembelajaran dibagi menjadi 5 tahap, yaitu: (1) melakukan penelitian pendahuluan, tahap ini diawali dengan identifikasi kebutuhan pembelajaran dan menentukan standard kompetensi mata pelajaran, melakukan analisis mata pelajaran, melakukan analisis pembelajaran, mengidentifikasi karakteristik dan perilaku siswa, menentukan kompetensi dasar serta indikator, menulis tes acuan patokan, mengembangkan materi pembelajaran, (2) pengumpulan bahan, diawali dengan pengumpulan bahan, pembuatan dan pengumpulan gambar animasi rekaman dan pengumpulan audio. (3) tahap ketiga pembuatan desain media software, pada tahap ini diawali dengan pembuatan desaian software, pembuatan naskah, pembuatan storyboard, pembuatan flowchartview. (4) tahap keempat membuat dan memproduksi media pembelajaran interaktif berbasis multimedia yang dilengkapi dengan petunjuk-petunjuk media seperti: petunjuk belajar, deskripsi singkat, kompetensi dasar, uraian materi, soalsoal latihan dan balikan, yang terakhir sebagai penutup adalah rangkuman, dan (5) tahap kelima yaitu review atau uji lapangan dalam rangka evaluasi formatif dan revisi produk. Evaluasi formatif terus berlangsung selama proses pengembangan mulai dari tahap analisis, desaian, produksi maupun implementasi hasil produk.

Dalam melakukan uji coba produk awal terhadap pengembangan ini perlu dilaksanakan dengan melalui beberapa langkah sebagai berikut: (1) Langkah awal menentukan sasaran uji coba yaitu ahli rancangan pembelajaran, ahli materi, ahli media dan peserta didik. Saran yang diharapkan dari para ahli masing-masing kesesuain uraian materi dengan standar kompetensi dan kompetensi dasar, keakuratan materi dan materi pendukung pembelajaran. Kemudian menganalisis konseptual serta revisi pengembangan tahap I. (2) Langkah yang kedua uji coba perorangan (uji coba satu-satu). Pada tahap ini produk telah diperbaiki pada revisi I (dilangkah 1) dan angket penilaian diberikan pada pemakai secara perorangan dan yang tujuannya untuk mengetahui kesahihan produk setelah diperbaiki berdasarkan tinjauan yang terdiri dari 3 siswa. Masukan dari uji coba 2 ini selanjutnya dipakai sebagai dasar dalam melakukan perbaikan-perbaikan terhadap produk revisi II. (3) Langkah yang ketiga uji coba kelompok kecil. Uji coba ini dilakukan untuk mengetahui apakah masih terdapat kekurangan-kekurangan yang perlu diperbaiki dari produk yang dikembangkan setelah diskusi baik berdasarkan tinjauan ahli maupun pada uji perorangan. Jika masih terdapat kekurangan maka beradasarkan masukan yang diperoleh akan dilakukan perbaikan III (revisi III). (4) Langkah yang keempat uji coba lapangan. Uji coba ini dilakukan untuk mengetahui apakah masih terdapat kekurangan-kekurangan yang perlu diperbaiki dari produk yang dikembangkan setelah diskusi baik berdasarkan tinjauan ahli maupun pada uji coba perorangan dan kelompok kecil. Jika masih terdapat kekurangannya maka berdasarkan masukan yang diperoleh akan dilakukan perbaikan revisi IV. Jika tidak maka produk dapat dinyatakan layak sebagai sumber belajar dilapangan.

\section{HASIL DAN PEMBAHASAN Hasil}

Media Pembelajaran Interaktif Matematika Kelas VI SD/MI ini dibuat sesuai dengan Kurikulum Tingkat Satuan Pendidikan (KTSP) di MIN Padang Bulan Rantauprapat. Media Pembelajaran ini juga sudah mendapat validasi dari ahli media dan desain yaitu Dosen Pascasarjana Universitas Negeri Medan Program Studi Teknologi Pendidikan, dan ahli materi yaitu Dosen Fakultas Matematika \& Ilmu Pengetahuan Alam Universitas Negeri Medan.

Proses pelaksanaan pengembangan media pembelajaran interaktif ini dilakukan secara bertahap. Proses pertama dalam kegiatan pengembangan ini adalah melakukan analisis kebutuhan di MIN Padang Bulan Rantauprapat dengan cara menebar angket kepada 12 guru dan 40 siswa dengan metode menguraikan defenisi dari media pembelajaran interaktif 
pada angket agar responden memiliki gambaran tentang pertanyaan dalam angket yang disampaikan. Kegiatan ini dilakukan pada bulan Agustus 2016. Hasil penelusuran dari angket yang disebar ditemukan bahwa 88,46\% dari siswa dan guru menyatakan membutuhkan media pembelajaran interaktif dalam proses pembelajaran agar proses pembelajaran berjalan lebih efektif, dan $100 \%$ siswa menyatakan membutuhkan media pembelajaran interaktif agar dapat mereka jadikan sebagai sarana pembelajaran secara individual.

Berdasarkan hasil analisis kebutuhan dapat disimpulkan bahwa pengembangan media pembelajaran interaktif memang sangat dibutuhkan oleh guru dan siswa dalam proses pembelajaran. Hasil wawancara secara lisan kepada guru bidang studi matematika menyatakan bahwa mereka membutuhkan media pembelajaran interaktif untuk menunjang proses pembelajaran karena mereka mengakui sulit mendapatkan media pembelajaran yang efektif untuk menyampaikan materi aspek bilangan, geometri dan pengukuran, dan pengolahan data bidang studi matematika pada kelas VI semester ganjil.

Kemudian tahap selanjutnya mendesain produk awal yang dilaksanakan melalui tahapan-tahapan, dimana pada tahap awal melakukan identifikasi kebutuhan pembelajaran, menentukan standar kompetensi mata pelajaran, membuat analisis pembelajaran, mengidentifikasi karakteristik dan prilaku awal peserta didik, menulis kompetensi dasar dan indikatornya, menulis tes acuan patokan, menyusun strategi pembelajaran, memilih mengembangkan bahan ajar, mendesain dan melakukan evaluasi formatif, merevisi kegiatan pembelajaran dan mendesain serta melaksanakan evaluasi sumatif.

Adapun pengujian terhadap produk dilaksanakan dengan serangkaian langkahlangkah dan revisi dimana uji coba dilakukan dengan empat tahapan yaitu: (1) evaluasi ahli materi, ahli desain pembelajaran dan ahli desain grafis, (2) uji coba perorangan, (3) uji coba kelompok kecil, (4) uji coba lapangan. Proses tahapan yang dilakukan disertai dengan melakukan revisi terhadap produk. Revisi juga dilakukan berdasarkan hasil uji coba dan analisis setelah melakukan uji coba, dan oleh karena itulah media pembelajaran interaktif pada mata pelajaran matematika telah memiliki status valid.

Hasil validasi dari ahli materi, ahli desain pembelajaran dan ahli desain media menunjukan bahwa media interaktif termasuk dalam kategori "Baik Sekali". Uji coba produk yang meliputi uji perorangan, uji kelompok kecil dan uji lapangan terhadap media interaktif menunjukan hasil pada kategori "Baik Sekali" seperti yang terlihat pada tabel 1 .

Tabel 1. Hasil validasi ahli dan uji coba lapangan

\begin{tabular}{|c|l|c|l|}
\hline No & \multicolumn{1}{|c|}{ Pengujian } & Persentase & \multicolumn{1}{|c|}{ Kategori } \\
\hline 1 & Ahli materi & $82,08 \%$ & Baik Sekali \\
\hline 2 & Ahli desain pembelajaran & $82,79 \%$ & Baik Sekali \\
\hline 3 & Ahli desain media & $89,55 \%$ & Baik Sekali \\
\hline 4 & Uji perorangan & $89,52 \%$ & Baik Sekali \\
\hline 5 & Uji kelompok kecil & $93,65 \%$ & Baik Sekali \\
\hline 6 & Uji lapangan & $96,38 \%$ & Baik Sekali \\
\hline
\end{tabular}

Media pembelajaran telah dinyatakan valid dan layak untuk digunakan dalam pembelajaran, kemudian dilakukan pengujian efektifitas produk. Penelitian ini dilaksanakan di kelas VI MIN Padang Bulan berlokasi di Jalan Padang Bulan Rantauprapat sebagai kelas eksperimen dan kelas VI SD Negeri 112143 Rantauprapat sebagai kelas kontrol. Langkah awal yang dilakukan terhadap ke dua kelas sampel sebelum memberikan perlakuan yang berbeda adalah dengan memberikan tes awal kepada siswa untuk mengetahui kemampuan awal masing-masing siswa kedua kelas. Kemudian, melakukan pembelajaran yang berbeda yaitu kelas eksperimen dengan media pembelajaran multimedia interaktif macromedia flash profesional 8 dan kelas kontrol dengan pembelajaran konvensional yang menggunakan buku teks. Kemudian pada akhir proses pembelajaran akan diberikan tes akhir untuk mengetahui hasil belajar siswa. Berdasarkan penelitian maka diperoleh hasil test awal (pretes) dan test akhir (postes) untuk kedua kelompok sampel yaitu masing-masing kelompok eksperimen dan kontrol adalah 30 orang siswa.

Hasil pretes dan postes pada siswa yang dibelajarkan dengan menggunakan 
media pembelajaran buku teks dan media pembelajaran interaktif macromedia flash dapat dilihat pada tabel dibawah ini. Setelah itu, dilakukan perhitungan sehingga diperoleh rata-rata pretes, postes dan simpangan baku seperti pada tabel 2.

Tabel 2. Statistik Data Pretes dan Postes

\begin{tabular}{|l|l|l|l|l|}
\hline \multirow{2}{*}{ Statistik } & \multicolumn{2}{c|}{ Kelas Eksperimen } & \multicolumn{2}{c|}{ Kelas Kontrol } \\
\cline { 2 - 5 } & \multicolumn{1}{|c|}{ Pretes } & \multicolumn{1}{c|}{ Postes } & \multicolumn{1}{c|}{ Pretes } & Postes \\
\hline Nilai tertinggi & 63,30 & 100,00 & 63,30 & 90,00 \\
\hline Nilai terendah & 30,00 & 73,30 & 26,70 & 63,30 \\
\hline Rata-rata & 44,33 & 86,55 & 46,22 & 74,55 \\
\hline Standar deviasi & 10,62 & 7,03 & 10,38 & 6,52 \\
\hline
\end{tabular}

Dilakukan pengujian normalitas data yang bertujuan untuk melihat sebaran data apakah terdistribusi normal atau tidak dengan menggunakan uji liliefors. Hasil uji normalitas dapat dilihat pada tabel 3.

Tabel 3. Uji Normalitas Pretes dan Postes

\begin{tabular}{|c|c|c|c|c|}
\hline Data & Kelas & $\mathrm{L}_{\text {hitung }}$ & $\mathrm{L}_{\text {table }}$ & Ket. \\
\hline \multirow{2}{*}{ Pretes } & Eksperimen & 0,151 & 0,161 & Normal \\
\cline { 2 - 5 } & Kontrol & 0,119 & 0,161 & Normal \\
\hline \multirow{2}{*}{ Postes } & Eksperimen & 0,132 & 0,161 & Normal \\
\cline { 2 - 5 } & Kontrol & 0,138 & 0,161 & Normal \\
\hline
\end{tabular}

Berdasarkan tabel 3. dapat dilihat bahwa pada kedua kelas $\mathrm{L}$ hitung $<\mathrm{L}$ tabel sehinga dapat disimpulkan bahwa pada data pretes dan postes kedua kelas berdistribusi normal pada taraf signifikansi $(\alpha=0,05)$.

Uji homogenitas data dilakukan untuk mengetahui kedua kelompok sampel berasal dari populasi yang sama atau homogen. Kriteria pengujian homogenitas adalah jika $F$ hitung $<\mathrm{F}$ tabel maka kelas eksperimen dan kelas kontrol dinyatakan homogen. Data hasil pengujian dapat dilihat pada tabel 4 .

Tabel 4. Hasil Uji Homogenitas Data Pretes dan Postes

\begin{tabular}{|c|c|c|c|}
\hline Data & $\mathrm{F}_{\text {hitung }}$ & $\mathrm{F}_{\text {tabel }}$ & Keterangan \\
\hline Pretes & 1,045 & 1,84 & Homogen \\
\hline Postes & 1,162 & 1,84 & Homogen \\
\hline
\end{tabular}

Berdasarkan tabel 4. dapat dilihat bahwa pada kedua kelas $F_{\text {hitung }}<\mathrm{F}_{\text {tabel }}$ sehinga dapat disimpulkan bahwa pada data pretes dan postes kedua kelas adalah homogen pada taraf signifikansi $(\alpha=0,05)$.

Uji hipotesis dilakukan untuk mengetahui seberapa efektif pembelajaran menggunakan media pembelajaran interaktif matematika mempengaruhi hasil belajar siswa. Pengujian dilakukan dengan menggunakan uji-t dua pihak, dimana hasil belajar siswa menggunakan media pembelajaran interaktif matematika dikontrol dengan hasil belajar dengan pembelajaran konvensional. Hasil pengujian hipotesis dapat dilihat pada tabel 5 .

Tabel 5. Hasil Uji t Data Postes

\begin{tabular}{|l|l|l|l|}
\hline \multicolumn{1}{|c|}{ Data } & \multicolumn{1}{|c|}{$\mathrm{t}_{\text {hitung }}$} & \multicolumn{1}{c|}{$\mathrm{t}_{\text {tabel }}$} & \multicolumn{1}{c|}{ Ket. } \\
\hline Postes & 6,855 & 1,67 & $\begin{array}{l}\text { Ha } \\
\text { diterima }\end{array}$ \\
\hline
\end{tabular}

Berdasarkan tabel 5. dapat dilihat bahwa pada kedua kelas $t_{\text {hitung }} \geq t_{\text {tabel }}$ sehinga dapat disimpulkan bahwa pembelajaran menggunakan media pembelajaran interaktif 
matematika berbasis Macromedia Flash Profesional 8 lebih baik dari konvensional pada taraf signifikansi $(\alpha=0,05)$.

\section{Pembahasan}

Pembelajaran matematika dapat diaplikasikan dalam bentuk media pembelajaran sehingga anak dapat menemukan pengalamannya. Media pembelajaran ini disusun dengan macromedia Flash profesional 8 yang memiliki kemampuan animasi yang interaktif, selain itu dapat mengimpor gambar dan animasi dari program lain sehingga media yang dihasilkan lebih menarik bila dipandu dengan macros. Media yang dikembangkan adalah media interaktif. Jadi akan ada penggabungan antara suara, gambar, tulisan animasi dan macros.

Produk pengembangan media pembelajaran interaktif pada mata pelajaran matematika merupakan materi pembelajaran yang telah dikembangkan dengan memperhatikan aspek pembelajaran dan media sebagai prinsip desain pesan pembelajaran. Penelitan pengembangan produk yang dilakukan ini diarahkan untuk menghasilkan suatu produk berupa media pembelajaran interaktif pada mata pelajaran matematika untuk siswa MIN Padang Bulan semester ganjil yang digunakan untuk meningkatkan proses pembelajaran maupun kompetensi siswa. Oleh sebab itu proses penelitian ini dilakukan dan diawali dengan, (1) studi pendahuluan, (2) kemudian mendesain media pembelajaran, (3) melakukan validasi produk dan melakukan revisi dan penyempurnaan berdasarkan analisis data validasi dari ahli materi, (4) ahli desain pembelajaran dan ahli rekayasa perangkat lunak yang dilanjutkan dengan uji coba perorangan, uji coba kelompok kecil, dan uji coba lapangan sehingga dihasilkan media pembelajaran yang baik digunakan sesuai dengan karakteristik mata pelajaran dan siswa sebagai pengguna. Hal ini sejalan dengan pendapat Borg dan Gall (1983:772) pada buku Education Research an Introduction yang mengemukakan bahwa penelitian pengembangan adalah penelitian yang berorientasi untuk mengembangkan dan memvalidasi produk-produk yang digunakan dalam pendidikan.
Aspek yang direvisi dan disempurnakan berdasarkan analisis data dan uji coba serta masukan dari ahli materi, ahli desain pembelajaran, ahli rekayasa perangkat lunak dan siswa selaku pengguna media pembelajaran interaktif ini, bertujuan untuk menggali beberapa aspek yang lazim dalam proses pengembangan suatu produk. Variabelvariabel media pembelajaran memiliki nilai rata-rata "Sangat Baik". Adapun variabel media pembelajaran yang dinilai meliputi kelayakan isi, penyajian, kebahasaan, pemrograman, dan kegrafikan.

Beberapa kegunaan dan manfaat dalam penggunaan media pembelajaran interaktif pada materi Bilangan, Geometri dan Pengukuran, dan Pengolahan Data sebagai berikut: (1) materi mudah dipahami karena konsep yang disajikan direncanakan untuk mempermudah siswa dan sistematis, (2) media pembelajaran interaktif memberi kesempatan siswa untuk belajar sesuai dengan kecepatan masing-masing individu, (3) belajar lebih cepat dan menarik sehingga tidak menimbulkan kebosanan karena dilengkapi dengan gambar-gambar dan animasi yang bervariasi. (4) media pembelajaran interaktif ini juga dapat digunakan sebagai alternatif media pembelajaran secara kelompok maupun individual.

Hasil pengolahan data penelitian yang dilakukan, terdapat perbedaan hasil belajar Matematika antara siswa yang dibelajarkan dengan menggunakan media pembelajaran interaktif dan siswa yang dibelajarkan dengan pembelajaran konvensional yaitu rata-rata hasil belajar siswa yang dibelajarkan dengan menggunakan media pembelajaran interaktif sebesar 86,55 lebih tinggi dibandingkan dengan siswa yang dibelajarkan dengan pembelajaran konvensional yaitu sebesar 74,55 .

Hasil penelitian ini sejalan dengan Hardiyanto, (2011) dalam pengembangan media pembelajaran interaktif pada mata pelajaran Fisika menggunakan perangkat lunak program Macromedia Flash professional 8 . Hasil penelitian menunjukan bahwa dengan pemanfaatan media pembelajaran Fisika berbasis macromedia flash profesional 8 sebagai media pembelajaran, dapat meningkatkan motivasi belajar siswa dari 49,56\% menjadi 67,33\%. 
Mursid (1997) dalam pengembangan buku ajar gambar teknik dengan menggunakan rancangan model Dick dan Carey, menyimpulkan bahwa buku ajar gambar teknik hasik pengembangan layak dipakai sebagai sumber belajar untuk matakuliah gambar teknik semester I di Jurusan Pendidikan Teknik Mesin FPTK IKIP Medan. Dalam pengembangannya digunakan pengembangan pembelajaran Dick dan Carey.

Rita (2014) menyimpulkan bahwa pengembangan pembelajaran Multimedia Interaktif Berbasis Internet Pelajaran Bahasa Inggris menguraikan bahwa berdasarkan uji ahli materi bahasa inggris kualifikasi sangat baik, uji coba perorangan kualifikasi sangat baik, uji coba kelompok kecil kualifikasi sangat baik dan uji coba lapangan kualifikasi sangat baik. Kualitas produk menunjukkan bahwa kelompok siswa yang dibelajarkan dengan menggunakan multimedia interaktif berbasis internet lebih tinggi dari kelompok siswa yang dibelajarkan dengan menggunakan media pembelajaran buku teks.

\section{PENUTUP}

Berdasarkan rumusan, tujuan, hasil dan pembahasan penelitian pengembangan media pembelajaran interaktif yang dikemukakan sebelumnya maka dapat disimpulkan sebagai berikut: (1) Hasil validasi dari ahli materi, ahli desain pembelajaran dan ahli media pembelajaran terhadap media pembelajaran interaktif pada mata pelajaran Matematika materi Aspek Bilangan, Geometri dan pengukuran dan Pengolahan data yang dikembangkan dengan Software Macromedia Flash 8 menunujukkan bahwa keseluruhan rata-rata dikategorikan "Sangat Baik" setelah dilakukan beberapa revisi sehingga media tersebut dapat digunakan untuk uji coba selanjutnya. Hasil validasi dari uji coba perorangan, uji coba kelompok kecil, dan uji coba lapangan terbatas terhadap media yang dikembangkan dengan Software Macromedia Flash 8 termasuk dalam kategori "Sangat Baik" sehingga dapat diterima dan layak digunakan sebagai media belajar. (2) Penggunaan media pembelajaran interaktif lebih efektif dapat meningkatkan hasil belajar bila dibandingkan dengan pembelajaran konvensioanal. Ratarata nilai hasil belajar dengan pembelajaran menggunakan media pembelajaran interaktif Macromedia Flash diperoleh sebesar 86,55 lebih baik dari konvensionalnya sebesar 74,55 .

\section{DAFTAR PUSTAKA}

AECT. 1986. Defenisi Teknologi Pendidikan. Jakarta: Rajawali, terjemahan oleh Yusuf Hadi Miarso.

Arief, Sadiman, 2012. Media Pendidikan, Jakarta: Raja Grafindo Persada

Arsyad Azhar. 2013. Media Pengajaran. Jakarta: Penerbit PT. Raja Grafindo

Borg, W.R. \& Gall, M.D. Gall. 1983. Education Research: An Introduction, Fifth Edition. New York: Longman.

Dick, W \& Carey, JO. 2005. The Systematic Design of Instruction, Seventh Edition. New Jersey: Pearson

Depdiknas, 2006. Kurikulum Tingkat Satuan Pendidikan ."Silabus Mata Pelajaran Matematika SD/MI". Jakarta : Pusat Kurikulum, Depdiknas

Miarso, Yusuf Hadi. 2004. Menyemai Benih Teknologi Pendidikan. Jakarta: Fajar Interpratama Mandiri.

Moeharti, Hw. 1986, Sistem-Sistem Geometri. Jakarta: Karunika Universitas Terbuka

Rita, \& Situmorang, Julaga. 2014. Pengembangan Pembelajaran Multimedia Interaktif Berbasis Internet Pelajaran Bahasa Inggris. Jurnal Teknologi Informasi dan Komunikasi dalam Pendidikan.Vol. 1, No. 2, Desember 2014. Program Studi Teknologi Pendidikan UNIMED.

Sudjana. 1992. Metode Statistik. Bandung: Tarsito.

Susilana Rudi \& Riyana Cepi . 2007. Media Pembelajaran: CV. Wacana Prima

Suparman, M Atwi. 2012. Desain Instruksional Modern, Jakarta: Erlangga.

Undang - Undang Republik Indonesia. Tentang Sistem Pendidikan Nasional. Nomor 20 Tahun 2003.

Tim Devisi Lidbang Madcoms. 2006. Mahir Dalam 7 Hari Macromedia Flash Profesional 8, Madiun: Andi . 
Jurnal TIK dalam Pendidikan, Vol. 8 No. 2 Desember 2021, p-ISSN: 2355-4983, e-ISSN: 2407-7488 